\title{
POSSIBLE FIRST SASKATCHEWAN SIGHTING OF FORK-TAILED FLYCATCHER
}

CAROL BJORKLUND, 102 - 1833 Coteau Ave., Weyburn, SK S4H 2X3

At approximately 7:00 a.m. on May 27, 1999, I was driving my morning school bus route north from Weyburn along Highway 35. Six miles south of Cedoux there is a pasture on the east side of the highway; a quarter mile to the west there is a deserted farmstead with trees, with a cultivated field intervening.

Off to the left, I caught the movement of a bird. Its flight was erratic and it appeared to be carrying something that was streaming out behind it. Was that a long straw, flowing like a light scarf and undulating gracefully as the bird flew? No, it was its tail!

The bird came from the west, flew east, five feet above the ground, and crossed directly in front of my bus. As it did so, I looked at its profile, and then looked down at it as it flew across the right ditch away from me. It was so close I almost ran into it. As it moved through, I glanced back to where it seemed to be swooping to land on a fencepost along the pasture perimeter.

Skies were clear. It was a warm, fresh morning. I had perfect visibility since I had been proceeding north without any sun glare in my eyes. The mainly gray bird was at least a foot long, perhaps slightly more, body rounded and short, tail a long, flexible streamer undulating behind, like the fluttering of a banner. It was charcoal above with a darker tail as I looked down on it. The tail feathers were black and almost one-and-ahalf times the length of the body. As it swooped toward the fence, it was white underneath.

It takes some distance to stop a 54passenger diesel bus going almost $100 \mathrm{kph}$. By the time I stopped and looked back, I could not see the bird. I had no binoculars and I had to keep to my schedule, so I made two quick phone calls from the bus. One to my husband, Martin Bailey in Weyburn, and the other to Bob Luterbach in Tyvan. My first thought was Scissor-tailed Flycatcher, and that is what I said to Bob Luterbach when I phoned.

When I returned at 8:00 a.m., both Martin and Bob were on the scene, joined by Ken Cox from Tyvan and Greg Bobbitt from Weyburn. Bob and Ken made a thorough search, but none of them saw the bird.

When I got home and looked at the National Geographic Field Guide, I saw that the bird looked like a Fork-tailed Flycatcher. I wanted to discount that identification because it seemed unlikely that a South American species would appear in Saskatchewan. Bob Kreba called a few minutes later, and advised me to read the April 1999 issue of Birding, still unread on my coffee table. In it, Mark Lockwood's article, "Possible anywhere, Fork-tailed Flycatcher," explained the wandering propensities of this species, adding that Fork-tailed Flycatchers "have a frustrating tendency to disappear shortly after being found, a vanishing act that only adds to their mystique. ... Fork-taileds are similar in size and tail length to Scissor-taileds ... in adults, the long outer rectrices are flexible and almost ribbon-like compared to the stiffer tail-streamers of the Scissor-tailed." Lockwood considered 92 records valid, from every month except March; 58 of the 120 sightings stayed only for one day. His map depicted sightings from the Great Lakes (west to Thunder Bay and Duluth) and the Atlantic coast south to Florida, but with scattered individual records from California, southwest Washington, Idaho and Alberta.

My sketch of the tail outline is attached. 


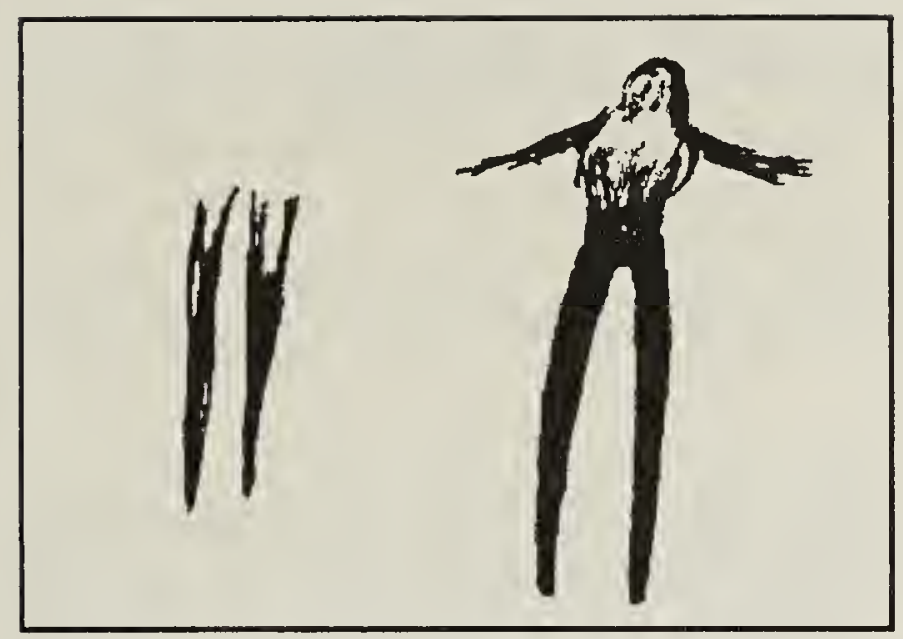

Sketch of tail

Carol Bjorklund

LOCKWOOD, M.W. 1999. Possible anywhere: Fork-tailed Flycatcher. Birding 31:126-138.

An egg of the Calliope hummingbird averages $12 \times 8 \mathrm{~mm}$, compared to a Trumpeter Swan egg of $111 \times 72 \mathrm{~mm}$.

The Rufous and Calliope Hummingbirds both breed in the Rocky Mountains of southwestern Alberta. The Rufous has been recorded in neighbouring Saskatchewan 21 times compared to only once for the Calliope.

Prairie Bobolinks still fly east before turning south along their ancestral route to South America. 